\title{
HOW DOES MARRIAGE AFFECT THE ALLOCATION OF ASSETS IN WOMEN'S DEFINED CONTRIBUTION PLANS?
}

\author{
Angela C. Lyons and Tansel Yilmazer*
}

CRR WP 2004-28

Released: November 2004

Draft Submitted: October 2004

\author{
Center for Retirement Research at Boston College \\ 550 Fulton Hall \\ 140 Commonwealth Ave. \\ Chestnut Hill, MA 02467 \\ Tel: 617-552-1762 Fax: 617-552-1750 \\ http://www.bc.edu/crr
}

* Angela C. Lyons is an Assistant Professor in the Department of Agricultural and Consumer Economics at the University of Illinois at Urbana-Champaign. Tansel Yilmazer is an Assistant Professor in the Department of Consumer Sciences and Retailing at Purdue University. The research reported herein was performed pursuant to a grant from the U.S. Social Security Administration (SSA) to the Center for Retirement Research at Boston College (CRR). This grant was awarded through the CRR's Steven H. Sandell Grant Program for Junior Scholars in Retirement Research. The opinions and conclusions are solely those of the authors and should not be construed as representing the opinions or policy of SSA or any agency of the Federal Government or the CRR. We also thank Julianne Cullen, Kristin Kleinjans, Ann Huff Stevens, seminar participants in the Department of Economics at the University of Illinois UrbanaChampaign and public finance participants in the 2004 CSWEP Junior Faculty Mentoring Program for providing us valuable feedback.

(C) 2004, by Angela C. Lyons and Tansel Yilmazer. All rights reserved. Short sections of text, not to exceed two paragraphs, may be quoted without explicit permission provided that full credit, including $\odot$ notice, is given to the source. 


\title{
About the Sandell Grant Program
}

This paper received funding from the Steven H. Sandell Grant Program for Junior Scholars in Retirement Research. Established in 1999, the Sandell program's purpose was to promote research on retirement issues by junior scholars in a wide variety of disciplines, including actuarial science, demography, economics, finance, gerontology, political science, psychology, public administration, public policy, sociology, social work, and statistics. The program was funded through a grant from the Social Security Administration (SSA).

\section{About the Center for Retirement Research}

The Center for Retirement Research at Boston College, part of a consortium that includes a parallel centers at the University of Michigan and the National Bureau of Economic Research, was established in 1998 through a grant from the Social Security Administration. The goals of the Center are to promote research on retirement issues, to transmit new findings to the policy community and the public, to help train rew scholars, and to broaden access to valuable data sources. Through these initiatives, the Center hopes to forge a strong link between the academic and policy communities around an issue of critical importance to the nation's future.

\author{
Center for Retirement Research at Boston College \\ 550 Fulton Hall \\ 140 Commonwealth Ave. \\ Chestnut Hill, MA 02467 \\ phone: 617-552-1762 fax: 617-552-1750 \\ e-mail: crr@bc.edu \\ http://www.bc.edu/crr
}

\section{Affiliated Institutions:}

American Enterprise Institute

Center for Strategic and International Studies

The Brookings Institution

Massachusetts Institute of Technology

Max Planck Institute for Demographic Research

Syracuse University

Urban Institute 


\begin{abstract}
Past studies that examine gender differences in investment decisions have treated married households as a single decision-making unit. This study improves upon traditional unitary bargaining models and estimates a series of unitary and collective-type models to investigate how a husband's age and relative control over financial resources affects the allocation of assets in women's defined contribution plans. Using data from the Survey of Consumer Finances, the results show that women who are married to less educated and older men are less likely to take on risk with their portfolios. Women who earn a greater share of the household's total earnings are also less likely to invest in risky assets. There is little evidence that the characteristics of the wife affect the husband's investment decisions. The findings have important policy implications, especially with respect to proposed Social Security reforms which would enable workers to choose how their personal security accounts are invested. (JEL J16, D81, G11)
\end{abstract}




\section{Introduction}

An increasing number of working men and women are now participating in defined contribution plans, and it is becoming more important that we better understand the factors that influence these types of investment decisions. Participants in defined contribution plans can decide how to allocate their retirement savings across different assets. The degree to which a participant is risk averse has a large impact on the asset allocation in his or her defined contribution plans and thus, the income for retirement.

Policy makers investigating the implications of proposed Social Security reforms have been concerned that many workers are investing their retirement assets too conservatively, allocating a larger share of their retirement savings to less risky assets with lower expected returns. Moreover, recent studies which investigate differences in risk aversion and investment decisions have identified gender differences in financial decision-making (Hinz, McCarthy, and Turner, 1997; Jianakoplos and Bernasek, 1998; Sundén and Surette, 1998; Bajtelsmit, Bernasek, Jianakoplos, 1999; Bernasek and Shwiff, 2001; Dwyer, Gilkenson, and List, 2002). These studies show that women are less likely than men to invest in risky assets. However, they have been unable to clearly identify how the interaction of gender and marital status affects the investment decisions of working men and women. The interaction is more complicated than previous research suggests.

Recent empirical studies that examine gender differences in investment decisions have treated married households as a single decision-making unit. The effect of marital status on the investment decisions of both married men and women has not been explicitly investigated. While theoretical models of family decision-making have been studied extensively, the implications of these models have not been discussed in the context of household savings and wealth and the allocation of assets in household portfolios. ${ }^{1}$ The investment choices of married couples are outcomes of joint decision-making. Therefore, we cannot conclude that women are conservative investors unless we study in detail the impact of marriage on women's investment decisions.

This study uses data from the 1995, 1998, and 2001 Survey of Consumer Finances to investigate the effect of marriage on the allocation of assets in women's defined contribution plans. Unitary and collective-type bargaining models are estimated to examine the effects of joint decision-making on the retirement investment decisions of married women. The Survey of Consumer Finances includes detailed information on the pension plans of the respondent and the respondent's spouse, such as the type of plan, account balance, and how the account is invested. Using this information and household demographics, this study examines how a husband's characteristics and relative control over financial resources affects the allocation of assets in married women's defined contribution plans.

The findings have important policy implications, especially with respect to proposed Social Security reforms which would enable workers to choose how their personal security

\footnotetext{
${ }^{1}$ The exceptions have been studies such as Browning (2000), Lundberg and Ward-Batts (2000), Lundberg, Startz, and Stillman (2001), which examine the effect of household bargaining on the savings and consumption behavior of the household.
} 
accounts are invested. Given concerns about the ability of households to make informed investment decisions, this research provides insight into the consequences of policy decisions related to the investment choices of married women versus married men.

\section{Literature Review}

As previously mentioned, several recent studies have examined gender differences in investment decisions and financial risk taking (Hinz et al., 1997; Jianakoplos and Bernasek, 1998; Sundén and Surette, 1998; Bajtelsmit et al., 1999; Bernasek and Shwiff, 2001; Dwyer, et al., 2002). The results of these studies show that women invest their asset portfolios more conservatively than men, and they exhibit less financial risk-taking. Within this body of literature, two key studies are commonly cited.

Jianakoplos and Bernasek (1998) investigate whether gender affects the coefficient of relative risk aversion. Using the framework developed in Friend and Blume (1975), they measure the coefficient of relative risk aversion by how the portfolio share of risky assets varies with wealth. Jianakoplos and Bernasek (1988) estimate the model separately for single men, single women and married couples. The results show that all three household types exhibit decreasing relative risk aversion. However, the estimated coefficient of risk aversion for single women is significantly less than that for single men indicating that as wealth increases, the proportion of risky assets in single women's portfolio increases less than that of single men. Their results show no significant difference in relative risk aversion for married couples and single females.

Using the information on pension coverage and pension plan characteristics in the 1992 and 1995 Survey of Consumer Finances, Sundén and Surette (1998) examine gender differences in the allocation of assets in defined contribution plans. Their results show that both gender and marital status affect the way individuals choose to allocate their retirement investments across different assets. They report that when the interaction of gender and marital status is omitted from the model, the estimates show that marital status has no effect on the investment decision, and women have a higher probability of investing their retirement plans in bonds than investing in a diversified portfolio between bonds and stocks. According to the results of the model that includes the interaction of marital status and gender, the behavior of married men and women is significantly different from that of single men and women. For example, single women and married men are less likely than single men to allocate a larger share of their defined contribution plans to stocks. Also, married women are more likely than single women to allocate a larger share of their pension plans to bonds.

The work of Sundén and Surette (1998) provides evidence that marital status plays an important role with respect to the investment behavior of women, and that the interaction of gender and marital status on investment decisions is more complicated than previous research has suggested. However, while theoretical models of family decision making and marital bargaining have been studied extensively, few empirical studies have examined the effect of marital bargaining on households savings. ${ }^{2}$ When examining the effect of marital bargaining, these studies focus on the fact that women typically live longer than men and wives are typically

\footnotetext{
${ }^{2}$ See Bergstrom (1997) for a survey of the theories of decision-making in the family.
} 
younger than their husbands (Lundberg and Pollak, 1994, 1996; Browning, 2000; Lundberg and Ward-Batts, 2000; Lundberg et al., 2001). These observations suggest that wives should prefer to hold greater net worth than their husbands as they approach retirement.

Lundberg and Ward-Batts (2000) estimate a bargaining model of household saving behavior, which includes both the characteristics of the husband and the wife. They show that the characteristics of both the husband and the wife, especially age and education, are significant determinants of household net worth. They also estimate another model of household savings, where age and education differences between husband $\mathrm{s}$ and wives are used as determinants of bargaining power. They hypothesize that if the wife has greater bargaining power in the household, then the household should have greater net worth than the household in which the wife has less power. Their results show that households in which husbands have more education than their wives have lower net worth.

Lundberg et al. (2001) use bargaining models to explain the observed decline in household consumption around the age of retirement. Since the bargaining power in the household depends on the relative control over resources, the husband's retirement from a job may cause a decline in his ability to influence consumption and saving decisions. The results of their model show evidence of a consumption drop at retirement for married couples but not for single households. Consistent with the life-cycle consumption models, single households do not exhibit a significant change in their consumption expenditures at retirement. Their results also show that a decline in consumption for married couples is more pronounced for households in which the age difference between the husband and wife is larger.

The results of these studies show how important marital bargaining is to household savings and consumption behavior. The investment choices for pension plans of married couples are also the outcome of joint decision-making. This study contributes to the literature by specifically examining the impact of marriage on women's retirement investment decisions.

The remainder of this paper is structured as follows. The next section discusses the methodology and empirical framework. The sections that follow describe the data and present the empirical findings. The final section summarizes the results and their implications for policy and future research.

\section{Methodology}

Previous research on gender differences in investment decisions focuses on estimating unitary bargaining models of family decision-making. The unitary model assumes that the husband and wife pool their income and maximize a social welfare function based on their individual utilities. This model implies that the degree of risk aversion exhibited by husbands, and thus the allocation of the ir retirement portfolios, is determined by the characteristics of their wives. Similarly, the degree of risk aversion exhibited by wives is affected by the characteristics of their husbands. However, previous literature that estimates unitary bargaining models has ignored the effect that spousal characteristics have on an individual's investment decisions and wealth. 
An alternative to a unitary model is a collective bargaining model of family decisionmaking. This model implies that the degree of risk aversion exhibited by a married individual is determined by both the characteristics of their spouse and their spouse's relative control over the household's resources. Collective models assume that whoever controls the resources within the household has a greater impact over the financial decisions within the household. ${ }^{3}$ For example, if the husband has greater bargaining power, then the degree to which the husband is risk averse may have a significant impact on the allocation of assets in both the husband's and wife's retirement plans and vice versa.

This study improves upon previous unitary models and estimates a series of unitary and collective-type bargaining models for both husbands and wives. The dependent variable for each model is a discrete outcome such that a respondent's investment choices for their defined contribution plan are defined as 1) investing in mostly bonds, 2) investing in a diversified portfolio, and 3) investing in mostly stocks. The data set used for this study does not collect information on the specific allocation of portfolio shares for each combination of stocks and bonds, and thus there is no clear ordering for each investment choice. For this reason, a multinomial logit model is used to analyze the investment choices of married men and women. Three different models are estimated--a unitary model that improves upon traditional unitary models and two collective-type models.

Respondent's investment choices under the unitary model are determined by the demographics of the respondent and general characteristics of the household. The characteristics of the respondent include age, education, ethnicity, earnings from wages and salaries, and whether the respondent has a managerial type occupation. Household characteristics include household net worth, the ratio of risky assets to financial wealth, the level of financial risk the household is willing to take, the number of children living in the home, and homeownership. ${ }^{4}$ These factors have been identified in previous literature as contributing to an individual's investment decisions. This unitary model improves upon traditional unitary models by also taking into account the spouse's characteristics such as age, education, and earnings. The model also includes whether the spouse has a defined contribution plan, which serves as a proxy for the characteristics of the investment plans and financial behaviors of the spouse.

The two collective-type bargaining models include the same factors as the unitary model and an additional set of factors that control for the spouse's relative control over the household's financial resources. It is important to acknowledge that the data used for this study does not include specific information about how financial decisions are made within the household. For this reason, the first collective model controls for household bargaining power by including the wife's share of total earnings. The second model includes both the wife's share of total earnings and a series of categorical variables that capture differences in age between the husband and wife. Differences in age are included to account for the possibility of a nonlinear relationship between age and investment behavior. These variables have been used as effective measures of

\footnotetext{
${ }^{3}$ See Lundberg and Pollack (1996) for a survey of household bargaining models and Lundberg and Pollack (1994) for a survey of non-cooperative bargaining models.

${ }^{4}$ The amount of risky assets held by the household in the ratio of risky assets to wealth excludes assets accumulated in retirement plans.
} 
household bargaining power in previous literature (i.e. Shelley J. Lundberg and Jennifer WardBatts, 2000; Shelly J. Lundberg et al., 2001).

The implications of the unitary and collective-type models are that the characteristics of the spouse and the spouse's relative control over financial resources are significant determinants of an individual's retirement investment decisions, especially those of married women.

\section{Data}

This study uses data from the 1995, 1998 and 2001 Survey of Consumer Finances (SCF) to estimate the multinomial logit models and determine the effect of marriage on the allocation of assets in women's defined contribution plans. The SCF is a triennial survey conducted by the Federal Reserve Board every three years. Each survey consists of a representative sample of the U.S. population and a supplement of high-wealth households drawn from tax information provided by the Internal Revenue Service. Given the dual nature of the data, all summary statistics reported in this paper are weighted to reflect the U.S. population as a whole.

The SCF contains detailed information on wealth, income, the employment status of the respondent and spouse, and other household characteristics. Although most information is collected at the household level, the SCF includes detailed questions on the respondent and spouse's pension eligibility and benefits from current and past employers. Information on pension plans includes the type of plan, account balance, and whether the respondent or spouse can decide how the account was invested. Respondents and spouses are classified as having a defined contribution plan (DCP) if they indicate 1) that they have an account-type pension plan and 2) that they have a choice about how the money is invested in the plan.

In the SCF, the respondent and the spouse are also asked a categorical question about how their account is invested: "How is the money in your defined contribution plan invested? Is it mostly in stocks, mostly in interest earning assets, or is it split between these?" Responses to this question are used to construct the dependent variable used in this paper and to analyze the relationship between married men and women's investment decisions and the characteristics of their spouses.

For the purposes of this study, the sample is restricted to married couples where either the husband and/or wife have a DCP at their current main job. ${ }^{5}$ The sample consists of 886 married individuals with defined contribution plans (DCPs) in 1995, 995 in 1998 and 1,225 in 2001. Of the total number of married individuals with DCPs $(\mathrm{N}=3,106), 2,050$ are married men and 1,056 are married women. Of the married men, only 28.4 percent have wives who have a DCP while over 47.5 percent of married women have husbands with a DCP. This is primarily due to the fact that a significant fraction of the spouses of married men are not working and thus not eligible to participate in a DCP through employment.

\footnotetext{
${ }^{5}$ The questions in the SCF are designed such that a respondent provides information about his or her "spouse or partner." For the purposes of this study, married households are defined as being legally married or living together with a member of the opposite sex. Less than 8.0 percent of the sample reported living together with a member of the opposite sex. Including these observations in the sample does not significantly alter the results.
} 
With respect to how the plans are invested, 11.1 percent of married men indicate that they invest their plan in mostly bonds, 34.9 percent in a diversified portfolio of stocks and bonds, and 53.9 percent in mostly stocks. The investment decisions of married women with respect to the allocation of assets in their defined contribution plans are very similar to married men. Over 12.0 percent or married women report that they invest their plan in mostly bonds, 34.2 percent in a diversified portfolio of stocks and bonds, and 53.1 percent in mostly stocks.

Table 1 provides information on how the demographics of the respondent and the characteristics of the spouse differ for married men and women with DCPs by the level of risk of their investment choices. An F-statistic was used to test the difference in means of the three levels of investment categories at the $.01, .05$, and 0.10 levels. For ease of exposition in discussing the findings, the specific levels of statistical significance are not discussed in the paper. However, they are presented in Table 1.

In general, regardless of gender, married individuals who invest in mostly stocks are more likely than married individuals who invest in mostly bonds to be younger, white, more educated, to have higher incomes, and to be living in a household that is willing to take average or above average financial risks. Those who have mostly stocks are also more likely to have a spouse who is younger and more educated and to have a spouse who has a defined contribution plan.

With respect to gender, there are several differences between married men and women worth noting. First, consider how differences in the respondent's characteristics appear to affect levels of investment risk for married men and women. With respect to those who invest in mostly stocks, married women are more likely than married men to have lower earnings and lower levels of net worth. Thirty-three percent of married women who invest in mostly stocks report net worth less than or equal to $\$ 50,000$ compared to 29.6 percent of married men who invest in mostly stocks. Moreover, approximately 22.0 percent of married women who invest in mostly stocks have net worth above $\$ 250,000$ compared to 25.6 percent of married men who invest in mostly stocks. Not surprisingly, men who invest in mostly stocks are more likely than men who invest in mostly bonds to have higher ratios of risky assets to wealth. For women, this ratio does not vary significantly by their investment choices.

With respect to other demographics, married men who invest in mostly stocks are more likely than those who invest in mostly bonds to have a managerial-type occupation and to own a home. These characteristics do not vary significantly for married women by their investment decisions. However, married women are more likely to have a managerial type occupation than married men. The number of children in the household does not vary significantly for married men or women.

Consider now the characteristics of the spouse and how these factors may affect the level of investment risk taken on by married men and women. Table 1 provides evidence which suggests that the characteristics of the spouse are more likely to affect the investment decisions of married women than married men. As the statistics indicate, married women who invest in mostly stocks are significantly more likely than those who invest in mostly bonds to have spouses who are younger, more educated, and to have defined contribution plans. In addition, 
married women who invest in mostly stocks are also more likely than those who invest in mostly bonds to be earning a greater share of the household's total earnings, and they are less likely to report annual earnings below $\$ 25,000$. Only 22.3 percent of married women who invest in mostly stocks indicate that they earn less than $\$ 25,000$ compared to 34.6 percent of married women who invest in mostly bonds. Finally, married women who invest in mostly bonds are more likely than those who invest in mostly stocks to have husbands who are "relatively" older than themselves. For example, 50.5 percent of married women who invest in mostly bonds have husbands who are three or more years older than them. Only 34.0 percent of married women who invest in mostly stocks have husbands who are three or more years older.

The trends are not as significant for married men. However, the statistics provide evidence which suggests that, compared to married men who invest in mostly bonds, married men who invest in mostly stocks are more likely to have spouses who are more educated and who have a defined contribution plan.

Overall, these statistics suggest that the characteristics of the spouse are more likely to affect the retirement investment decisions of married women than married men. The spouse's relative control over financial resources also appears to have a greater impact on the investment decisions of married women. The next section tests whether the empirical analysis supports these statistical findings.

\section{Results}

The results from the multinominal logit models for married men and women are presented in Tables 2 and 3. The observations from the 1995, 1998, and 2001 survey years have been pooled and year dummies are included to control for aggregate economic effects. ${ }^{6}$ The first two columns of each table present the coefficients for the unitary model (Model 1). The remaining columns present the results for the two collective-type bargaining models (Model 2 and Model 3). For each model, the coefficients are presented for the categories "mostly bonds" and "mostly stocks." The "diversified" category is used as the reference category such that the effect of each variable refers to its effect on the likelihood of choosing "mostly stocks" or "mostly bonds" relative to the likelihood of choosing a "diversified" portfolio. The findings are discussed without reference to this normalization.

Table 2 presents the results for married men. In this table, the unitary model includes only the characteristics of the spouse while the first collective model includes the characteristics of the spouse and the wife's share of total earnings and the second collective model includes all of the previous variables and a series of categorical variables that capture age differences between the husband and wife. In general, there is little evidence that the characteristics of the wife and her relative control over the household's resources have an effect on the investment decisions of married men. The wife's share of total earnings and whether she has a DCP do not appear to have a significant effect on the likelihood of investing in "mostly bonds" or "mostly stocks" for married men. Age differences between the husband and the wife also do not appear to have a significant effect. The exception is that husbands who have more educated wives are significantly more likely to invest their plans in "mostly stocks."

\footnotetext{
${ }^{6}$ The results are robust when the model is estimated separately for each survey year.
} 
Table 2 further reveals that, with respect to demographic characteristics, married men who are older and who have a managerial-type occupation are more likely to invest their DCP in "mostly bonds" while those who are homeowners are less likely to invest in "mostly bonds." Not surprisingly, the household's ratio of risky assets to financial wealth and the household's willingness to take average or above average financial risks is positively associated with investing in more risky assets.

Table 3 presents the estimates from the multinomial logit models for married women. With respect to the characteristics of the spouse, several points are worth noting. First, married women who are married to men who are older and who have more education are significantly less likely to invest in "mostly bonds" as are those who are married to men with a DCP. On the other hand, age differences between the husband and the wife significantly decrease the likelihood of married women investing in "mostly stocks." Unlike the findings from the model for married men, these findings provide evidence that the characteristics of the spouse and his relative control over the financial resources have a significant effect on the investment choices of married women.

With respect to demographics, women with lower earnings are less likely to invest in "mostly bonds" while women with managerialtype occupations are significantly more likely to invest in "mostly bonds." For married women, the number of children is also positively associated with investing in "mostly bonds," whereas the number of children does not significantly effect the investment decisions of married men. Not surprisingly, the household's willingness to take average or above average financial risks increases the likelihood that married women invest in more risky assets.

Table 4 summarizes the findings and presents the marginal effects for Model 3 with respect to how defined contribution plans are invested (i.e. "mostly bonds," "split between bonds and stocks," and "mostly stocks"). Marginal effects have been calculated at the mean values and are reported for the spousal characteristics since they are the main focus of this paper (See Long (1997), pp. 165-167 for the details of the calculation). As previously mentioned, the characteristics of the spouse appear to have little effect on married men except that an additional year of education for the spouse results in a 1.3 percentage point increase in the probability married men invest in "mostly stocks."

For married women, the marginal effects suggest that when the wife has more bargaining power (i.e. greater share of total earnings), the wife is less likely to invest in risky assets. When the husband is less educated and 3-5 years older than the wife, she is also less likely to invest in risky assets. Specifically, an additional year of education for the spouse results in a 0.7 percentage point decrease in the probability that married women invest in "mostly bonds." Also, married women who have a spouse with a DCP are 3.7 percentage points less likely to invest in "mostly bonds." The most revealing finding is that married women who have a greater share of total household earnings are significantly more likely to invest in "mostly bonds" and less likely to invest in "mostly stocks." At the sample mean values, a 0.1 unit increase in the wife's share of total earnings results in a 2.3 percentage point decrease in the likelihood of investing in "mostly stocks" and a 1.1 percentage point increase in the likelihood of investing in "mostly 
bonds." With respect to age differences between the husband and the wife, married women who have husbands who are 3 to 5 years older than them are 14.6 percentage points less likely to invest in "mostly stocks" and 5.9 percentage points more likely to invest in "mostly stocks."

\section{Discussion and Conclusions}

Past studies that examine gender differences in investment decisions find that women are less likely than men to invest in risky assets. However, these studies treat married households as a single decision-making unit. Little attention has been given to investigating the affect that joint decision-making has on the investment decisions of married men and women. This study improves upon traditional unitary models and estimates a series of unitary and collective bargaining models to investigate the effect of marriage on the allocation of assets in women's defined contribution plans. The results show that women who are married to less educated and older men are less likely to take on risk with their portfolios. Moreover, women who earn a greater share of the household's total earnings are also less likely to invest in risky assets. There is little evidence that the characteristics of the wife affect the husband's investment decisions.

The findings from this study suggest that previous research may not have adequately controlled for marital status and socio-economic determinants. The findings further suggest that marriage may have a significant impact on the resources available to women during their retirement years. Specifically, marriage may be increasing the gap between men and women's retirement savings, especially for households where the husband is less educated and older than the wife. For these households, the privatization of Social Security may further magnify the gap. In these cases, married women may be more likely to retire with significantly lower levels of retirement savings than married men. Given that married couples are more likely to divorce than earlier generations and that women have greater longevity than men, the ability of women to maintain consumption after retirement could be further restricted.

In lieu of increases in the number of defined contribution pension plans and legislative proposals recommending the privatization of Social Security, it is important that financial professionals develop a better understanding of family decision-making with respect to household finances. Marriage may have a significant impact on the resources available to women during their retirement years. Financial professionals may want to collect more information from their clients about financial decision-making processes within a household, especially how decisions are being made and who is managing the financial resources. There is a role for financial education to help women understand that it may be in their best interest to become more involved in the financial decisions of the household.

Overall, while this study provides substantial insight into the impact that marriage has on women's retirement investment decisions, it is primarily descriptive and limited in the following respects. First, the characteristics of the spouse may be proxies for the characteristics of the investment plans or other financial behaviors of the spouse, which limits the inferences that can be made. The model in this paper controls for whether the spouse has a defined contribution plan. However, a more complete analysis would take into account in more detail how the investment decisions of the spouse affect the investment decisions of the respondent. Unfortunately, these variables as well as others are likely to be endogenous or simultaneously determined with the DCP investment decisions of the respondent. Given data limitations, these 
econometric issues are difficult to address and our analysis is unable to account for these added complications.

A second limitation is that the data set used for this study does not include specific information on the process of financial decision-making within the household. We do not know which spouse is specifically making the financial decisions regarding the allocation of assets and how and when those decisions are being made. We also are unable to adequately control for the impact an employer may be having on these decisions. There is the additional concern that gender and marital differences in investment behavior may be driven in part by self selection into jobs with defined contribution plans. For example, individuals with preferences for risk may seek employment with firms that are offering plans with choice. For this reason, additional research is needed to determine if the findings of this study are robust for other types of investments.

However, even with these limitations, the findings of this study have important policy implications, especially with respect to proposed Social Security reforms which would enable individuals to choose how their personal security accounts are invested. However, further research is needed to investigate financial decision-making within the household before our understanding is complete. 


\section{REFERENCES}

Bajtelsmit, Vickie and Bernasek, Alexandra. "Why Do Women Invest Differently than Men?" Financial Counseling and Planning, 1996, 7, pp. 1-10.

Bajtelsmit, Vickie and VanDerhei, Jack L. "Risk Aversion and Pension Investment Choices," in Michael Gordon, Olivia Mitchell, and Marc Twinney, eds., Positioning Pensions for the Twenty-First Century. Philadelphia: University of Pennsylvania Press, 1997, pp. 45-66.

Bajtelsmit, Vickie, Bernasek, Alexandra, and Jianakoplos, Nancy. "Gender Differences in Defined Contribution Pension Decisions." Financial Services Review, 1999, 8, pp. 1-10.

Bergstrom, Theodore C. "A Survey of Theories of the Family," in M. R. Rosenzweig and O. Stark, eds., Handbook of Population and Family Economics. Elsevier Science, 1997, pp. $21-74$.

Bernasek, Alexandra and Shwiff, Stephanie. "Gender, Risk, and Retirement." Journal of Economic Issues, June 2001, 35(2), pp. 345-56.

Browning, Martin. “The Saving Behavior of a Two-person Household." Scandinavian Journal of Economics, 2000, 102(2), pp. 235-51.

Dwyer, Peggy D., Gilkenson, James H., and List, John A. "Gender Differences in Revealed Risk Taking: Evidence from Mutual Fund Investors.” Economic Letters, 2002, pp. 151-58.

Friend, Irwin and Blume, Marshall E "The Demand for Risky Assets." American Economic Review, December 1975, 65(5), pp. 900-22.

Haliassos, Michael and Bertaut, Carol. "Why Do So Few Hold Stocks?" The Economic Journal, September 1995, 105, pp. 1110-129.

Hinz, Richard, McCarthy, David, and Turner, John. "Are Women Conservative Investors? Gender Differences in Participant-Directed Pension Investments," in Michael Gordon, Olivia Mitchell, and Marc Twinney, eds., Positioning Pensions for the Twenty-First Century. Philadelphia: University of Pennsylvania Press, 1997, pp. 91-103.

Jianakoplos, Nancy A. and Alexandra Bernasek. “Are Women More Risk Averse?” Economic Inquiry, October 1998, 36, pp. 620-30.

Long, Scott J. Regression Models for Categorical and Limited Dependent Variables. Thousand Oaks, CA: Sage Publications, 1997.

Lundberg, Shelly J., Startz, Richard and Stillman, Steven. "The Retirement-Consumption Puzzle: A Marital Bargaining Approach.” Working Paper, July 2001. 
Lundberg, Shelly and Pollak, Robert. "Bargaining and Distribution in Marriage." Journal of Economic Perspectives, Fall 1996, 10(4), pp. 139-58.

Lundberg, Shelly and Pollak, Robert. "Noncooperative Bargaining Models of Marriage." American Economic Review, 1994, 84(2), pp. 132-37.

Lundberg, Shelly J and Ward-Batts, Jennifer. "Saving for Retirement: Household Bargaining and Household Net Worth.” Working Paper, April 2000.

Papke, Leslie. "How Are Participants Investing Their Accounts in Participant-Directed Individual Account Pension Plans?" American Economic Review, 1998, 88(2), pp. 212 16.

Samuelson, Paul A. “Social Indifference Curves.” Quarterly Journal of Economics, 1956, 70(1), pp. 1-22.

Sundén, Annika E. and Surette, Brian. "Gender Differences in the Allocation of Assets in Retirement Savings Plans.” American Economic Review, 1998, 88(2), pp. 207-11. 
Table 1

Descriptive Statistics for Married Men and Women with Defined Contribution Plans



$* * *$ The difference in the means of the three groups is significant at the 0.01 level. ** The difference in the means of the three groups is significant at the 0.05 level. * The difference in the means of the three groups is significant at the 0.10 level. 
Table 2

Multinomial Logit for Married Men with Defined Contribution Plans

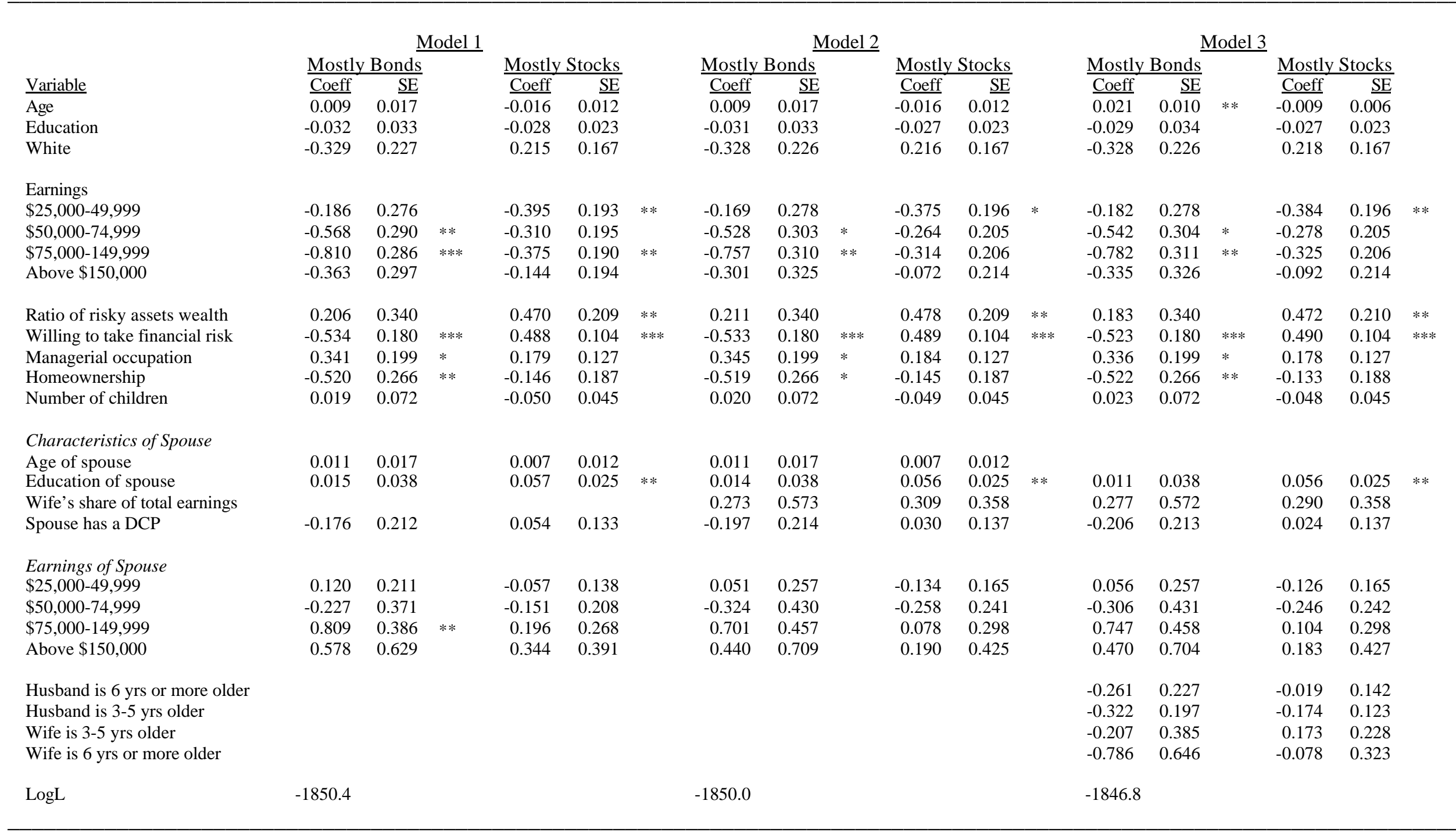

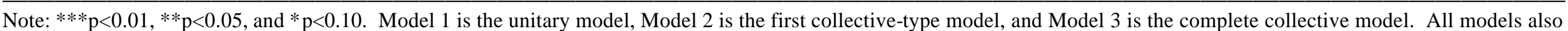
include dummy variables to control for household net worth and survey year. Robust standard errors are in parentheses. 
Table 3

Multinomial Logit for Married Women with Defined Contribution Plans

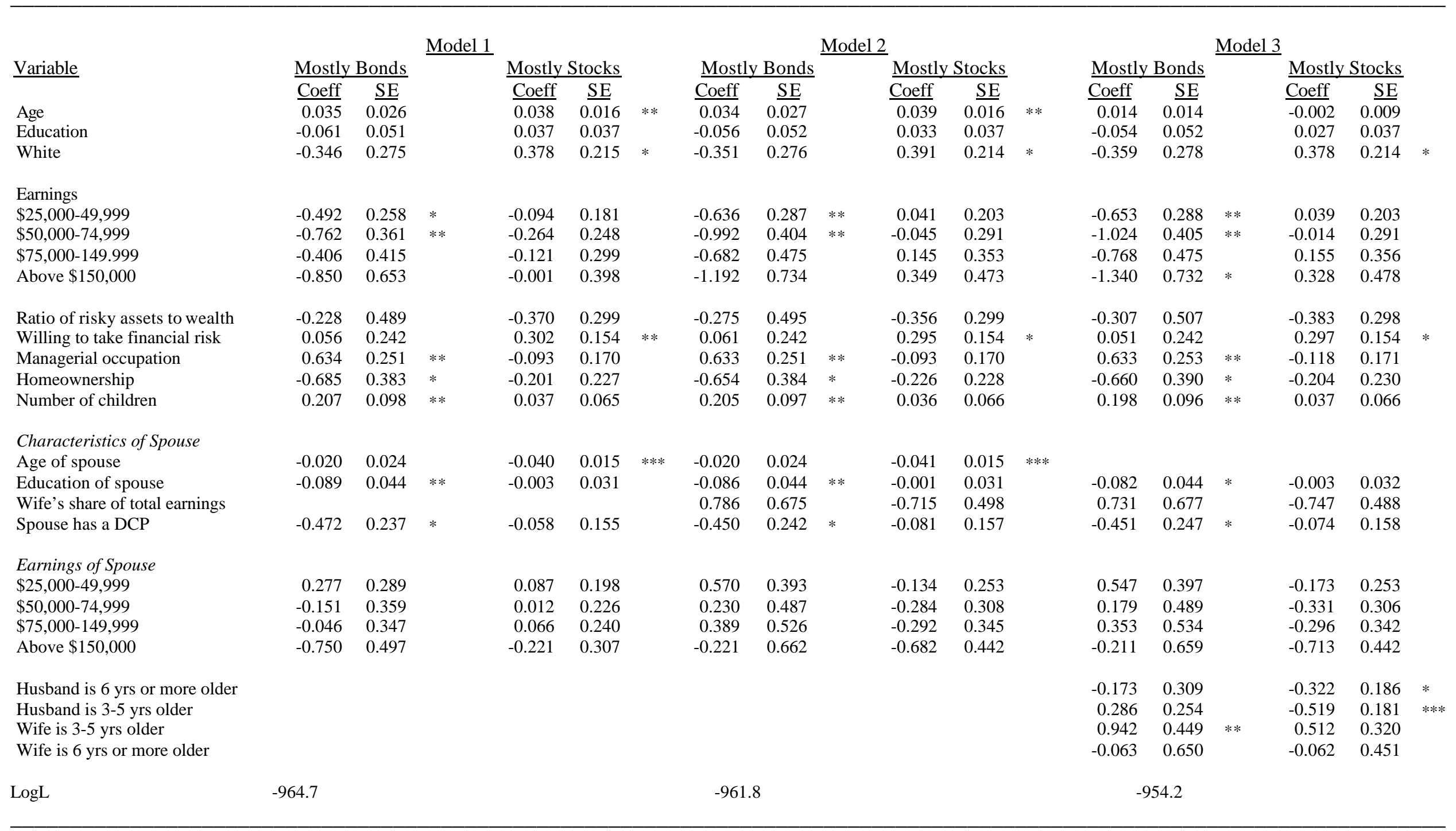

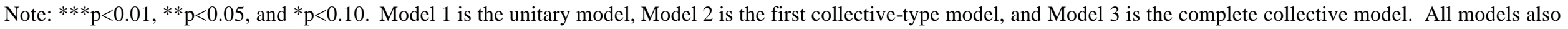
include dummy variables to control for household net worth and survey year. Robust standard errors are in parentheses. 
Table 4

Marginal Effects for Married Men and Women for Model 3 (complete collective model)

\begin{tabular}{|c|c|c|c|c|c|c|c|c|c|c|c|}
\hline \multirow[b]{2}{*}{$\underline{\text { Spousal Characteristic }}$} & \multirow[b]{2}{*}{$\begin{array}{l}\text { Mostly } \\
\text { Bonds }\end{array}$} & \multicolumn{4}{|c|}{ Married Men } & \multicolumn{5}{|c|}{ Married Women } & \\
\hline & & $\begin{array}{r}\text { Stocks } \\
\& \text { Bonds } \\
\end{array}$ & & $\begin{array}{l}\text { Mostly } \\
\text { Stocks }\end{array}$ & & $\begin{array}{l}\text { Mostly } \\
\text { Bonds }\end{array}$ & & $\begin{array}{c}\text { Stocks } \\
\& \text { Bonds }\end{array}$ & & $\begin{array}{l}\text { Mostly } \\
\text { Stocks }\end{array}$ & \\
\hline Education of spouse & -0.002 & -0.011 & $* *$ & 0.013 & $* *$ & -0.007 & $* *$ & 0.003 & & 0.004 & \\
\hline Wife's share of total earnings & 0.009 & -0.066 & & 0.057 & & 0.107 & $* *$ & 0.118 & & -0.225 & $* *$ \\
\hline Spouse has a DCP & -0.019 & 0.002 & & 0.017 & & -0.037 & $*$ & 0.030 & & 0.007 & \\
\hline \multicolumn{12}{|l|}{ Earnings of spouse } \\
\hline$\$ 25,000-49,999$ & 0.012 & 0.022 & & -0.034 & & 0.066 & & 0.010 & & -0.076 & \\
\hline$\$ 50,000-74,999$ & -0.014 & 0.060 & & -0.046 & & 0.037 & & 0.056 & & -0.093 & \\
\hline$\$ 75,000-149,999$ & 0.077 & -0.051 & & -0.026 & & 0.055 & & 0.040 & & -0.095 & \\
\hline Above $\$ 150,000$ & 0.036 & -0.051 & & 0.015 & & 0.016 & & 0.149 & & -0.165 & $*$ \\
\hline Husband is 6 yrs or more older & -0.021 & 0.012 & & 0.008 & & 0.001 & & 0.070 & & -0.071 & \\
\hline Husband is $3-5$ yrs older & -0.018 & 0.045 & & -0.027 & & 0.060 & $* *$ & 0.086 & $* *$ & -0.146 & $* * *$ \\
\hline Wife is $3-5$ yrs older & -0.025 & -0.028 & & 0.053 & & 0.067 & & -0.123 & $* *$ & 0.055 & \\
\hline Wife is 6 yrs or more older & -0.049 & 0.037 & & 0.012 & & -0.002 & & 0.014 & & -0.012 & \\
\hline
\end{tabular}

Note: $* * * \mathrm{p}<0.01, * * \mathrm{p}<0.05$, and $* \mathrm{p}<0.10$. Marginal effects have been calculated at the mean values. 


\section{RECENT WORKING PAPERS FROM THE \\ CENTER FOR RETIREMENT RESEARCH AT BOSTON COLLEGE}

How Does Marriage Affect the Allocation of Assets in Women's Defined

Contribution Plans?

Angela C. Lyons and Tansel Yilmazer

Why Don't Americans Save?

Barry Bosworth, November 2004

How Do Pensions Affect Expected and Actual Retirement Ages?

Alicia H. Munnell, Robert K. Triest, and Natalia A. Jivan

Sliding Into Poverty? Cross-National Patterns of Income Source Change and Income Decay in Old Age

James M. Williamson and Timothy M. Smeeding

The Well-Being Of Retirees: Evidence Using Subjective Data

Keith A. Bender, November 2004

The Impact of Aging on Financial Markets and the Economy: A Survey

Barry P. Bosworth, Ralph C. Bryant and Gary Burtless, October 2004

Social Security Personal-Account Participation with Government Matching Gary V. Engelhardt and Anil Kumar, October 2004

Providing Guarantees in Social Security

Karen E. Smith, C. Eugene Steuerle, and Pablo Montagnes, August 2004

Deferring Income in Employer-Sponsored Retirement Plans: The Dynamics of Participant Contributions

Karen E. Smith, Richard W. Johnson, and Leslie A. Muller, August 2004

Reform Model Two of the President's Commission to Strengthen Social Security: Distributional Outcomes Under Different Economic and Behavioral Assumptions Melissa M. Favreault, Joshua H. Goldwyn, Karen E. Smith, Lawrence H. Thompson, Cori E. Uccello, and Sheila R. Zedlewski, August 2004

An Analysis of How Individuals React to Market Returns in One 401(k) Plan Julie Agnew, April 2004

The Effects of Health Insurance and Self-Insurance on Retirement Behavior Eric French and John Bailey Jones, April 2004

All working papers are available on the Center for Retirement Research website (http://www.bc.edu/crr) and can be requested by e-mail (crr@bc.edu) or phone (617-552-1762). 